\title{
PENGARUH KINERJA KEUANGAN KABUPATEN/ KOTA TERHADAP ALOKASI BELANJA MODAL DI PROVINSI SULAWESI UTARA
}

\author{
Sylvia Febriany Gerungan \\ David P.E. Saerang \\ Winston Pontoh
}

sylviagerungan@gmail.com

\begin{abstract}
The regional autonomy policy gives more chance to local goverment for managing their own financial. To determine the success of local goverment in managing their own financial, Financial Performance Analysis can be used. The objective of this research is to determine the influence of regional financial performance toward the capital expenditure allocation in forward years of regency/city of North Sulawesi. The data analysis method used in this research is regression. The results show that, simultaneously, the Regional Financial Independence ratio, Regional Financial Dependence ratio, Local Original Revenue Effectiveness ratio, Capital Expenditure Effectiveness ratio, Efficiency ratio, and Expenditure Harmony ratio significantly effect the Capital Expenditure Allocation. Partially, the Regional Financial Independence ratio and Efficiency ratio, significantly, have a negative effect toward the Capital Expenditure Allocation. While, the Local Original Revenue Effectiveness ratio and Expenditure Harmony ratio have a positive effect toward the Capital Expenditure Allocation. The Regional Financial Dependence ratio and Capital Expenditure Effectiveness have no significant effect toward the Capital Expenditure Allocation.
\end{abstract}

Keywords: Financial Performance, Regional Financial Independence, Regional Financial Dependence, Effectiveness, Efficiency, Expenditure Harmony, Capital Expenditure.

\section{PENDAHULUAN}

\subsection{Latar Belakang}

Sejak diberlakukannya Undang-Undang No. 22 tahun 1999 dan Undang-Undang No. 25 tahun 1999, yang kemudian diubah menjadi Undang-Undang No. 32 tahun 2004 dan Undang-Undang No. 33 tahun 2004 tentang Pemerintah Daerah dan tentang Perimbangan Keuangan Antara Pusat dan Daerah, kewenangan pemerintah daerah menjadi lebih besar dalam mengelola sumber daya dan keuangan daerahnya sendiri. Berkurangnya campur tangan pemerintah pusat diharapkan dapat meningkatkan kemandirian pemerintah daerah dalam mengelola keuangan daerahnya. Kemampuan pemerintah daerah dalam mengelola keuangan daerahnya dapat diukur dengan analisis kinerja keuangan daerah. Kinerja keuangan terdiri dari rasio-rasio keuangan. Rasio-rasio keuangan ini digunakan untuk: menilai kemandirian keuangan daerah dalam membiayai penyelengaraan otonomi daerah; mengukur efektivitas dan efisiensi dalam merealisasikan pendapatan daerah; mengukur sejauh mana aktivitas pemerintah daerah dalam membelanjakan pendapatan daerahnya; mengukur kontribusi masing-masing sumber pendapatan dalam pembentukan pendapatan daerah; melihat pertumbuhan/perkembangan perolehan pendapatan dan pengeluaran yang dilakukan selama periode waktu tertentu (Halim, 2007:230).

Seperti halnya rasio-rasio pada perusahaan swasta, rasio-rasio keuangan daerah merupakan perbandingan angka-angka dalam laporan keuangan pemerintah daerah. Namun, dikarenakan adanya perbedaan jenis dan struktur laporan keuangan pemerintah daerah dengan perusahaan swasta, maka rasiorasio keuangan daerah memiliki sedikit perbedaan. Rasio-rasio yang lazim digunakan dalam analisis kinerja keuangan pemerintah daerah, merupakan perbandingan angka-angka dalam Laporan Realisasi Anggaran (LRA). Rasio-rasio yang sering digunakan dalam analisis kinerja keuangan pemerintah daerah adalah Rasio Kemandirian Keuangan Daerah, Rasio Ketergantungan Keuangan Daerah, Rasio Efektivitas PAD, Rasio Efisiensi Keuangan Daerah, Rasio Keserasian Belanja Dan Rasio Pertumbuhan. 
Kinerja pengelolaan keuangan daerah di Provinsi Sulawesi Utara secara umum berada di atas rata-rata. Pendapatan pemerintah daerah Sulawesi Utara terus meningkat, namun sebagian besar pendapatan tersebut merupakan dana perimbangan dari pemerintah pusat. Komposisi belanja pemerintah daerah secara umum mengalami perbaikan di mana porsi belanja modal terus meningkat, namun komposisi belanja terbesar masih didominasi oleh belanja pegawai. Pendapatan Asli Daerah (PAD) kabupaten dan kota di Sulawesi Utara relatif rendah dan ketergantungan pendapatan akan transfer pemerintah pusat semakin besar. Hal ini kurang selaras dengan tujuan otonomi daerah. Pemerintah provinsi dan kebanyakan kabupaten dan kota di Sulawesi Utara memiliki SiLPA yang besar. Ini menggambarkan bahwa pemerintah daerah kurang dapat menyerap anggaran yang ada dan masih bisa melakukan program dan kegiatan yang penting dalam pelayanan kepada masyarakat (Bank Dunia, 2011).

Belanja modal merupakan angka yang memberi gambaran tentang upaya pemerintah daerah dalam meningkatkan pembangunan daerahnya. Untuk mendorong pembangunan daerah dan pertumbuhan ekonomi, pemerintah daerah perlu memberikan porsi yang lebih besar pada belanja modal dalam komposisi belanja daerah. Belanja modal yang disebut juga belanja pembangunan, mempunyai dampak positif dan signifikan terhadap pertumbuhan ekonomi. Menurut Priyo Hari Adi (2006) pertumbuhan ekonomi yang selama ini terjadi sangat ditentukan oleh faktor belanja pembangunan daerah. Pembangunan infrastruktur dan fasilitas-fasilitas publik dapat meningkatkan kualitas pelayanan kepada masyarakat dan dapat menjadi daya tarik bagi para investor. Hal ini dapat memberikan peluang pada peningkatan pendapatan per-kapita daerah dan dapat mendorong pertumbuhan ekonomi. Semakin besar alokasi belanja modal berarti pemerintah semakin serius dalam membangun daerah dan mensejahterakan masyarakat. Namun saat ini komposisi belanja masih didominasi oleh belanja operasional terutama belanja pegawai. Pada kabupaten dan kota Provinsi Sulawesi Utara porsi belanja modal masih tergolong kecil dibandingkan dengan belanja operasional. Rasio belanja modal terhadap total belanja tahun 2011 rata-rata untuk semua kabupaten/kota Provinsi Sulawesi Utara adalah 27,69\%, dan rasio belanja modal terbesar ada di kabupaten Bolaang Mongondow Timur yaitu sebesar 49,16\%.

Penelitian ini dilakukan untuk melihat pengaruh kinerja keuangan terhadap alokasi belanja modal pada kabupaten dan kota provinsi sulawesi utara. Variabel yang digunakan dalam penelitian ini meliputi: Rasio Kemandirian Keuangan Daerah, Rasio Ketergantungan Keuangan Daerah, Rasio Efektifitas PAD, Rasio Efektivitas Belanja Modal, Rasio Efisiensi Keuangan Daerah, Dan Rasio Keserasian Belanja. Beberapa variabel telah digunakan oleh penelitian-penelitian sebelumnya, seperti Rasio Kemandirian Keuangan Daerah, Rasio Ketergantungan Keuangan Daerah, Rasio Efektivitas PAD, dan Rasio Efisiensi. Sedangkan beberapa variabel ditambahkan untuk memperluas referensi tentang rasiorasio yang memiliki pengaruh terhadap pengalokasian belanja modal. Rasio Efektivitas Belanja Modal ditambahkan, untuk melihat apakah semakin efektif penyerapan anggaran belanja modal akan

mempengaruhi penetapan anggaran belanja modal tahun berikutnya. Rasio Keserasian belanja ditambahkan untuk melihat apakah pengalokasian belanja modal dipengaruhi oleh tren belanja modal di tahun-tahun sebelumnya.

\subsection{Perumusan Masalah}

Berdasarkan latar belakang dapat diformulasikan beberapa masalah antara lain sebagai berikut:

1) Apakah Kemandirian Keuangan Daerah berpengaruh secara signifikan terhadap Alokasi Belanja Modal?

2) Apakah Ketergantungan Keuangan Daerah berpengaruh secara signifikan terhadap Alokasi Belanja Modal?

3) Apakah Efektivitas PAD berpengaruh secara signifikan terhadap Alokasi Belanja Modal?

4) Apakah Efektivitas Belanja Modal berpengaruh secara signifikan terhadap Alokasi Belanja Modal?

5) Apakah Efisiensi Keuangan Daerah berpengaruh secara signifikan terhadap Alokasi Belanja Modal?

6) Apakah Keserasian Belanja berpengaruh secara signifikan terhadap Alokasi Belanja Modal? 
7) Apakah Kemandirian Keuangan Daerah, Ketergantungan Keuangan Daerah, Efektivitas PAD, Efektivitas Belanja Modal, Efisiensi, dan Keserasian Belanja berpengaruh secara signifikan terhadap Alokasi Belanja Modal?

\subsection{Tujuan Penelitian}

Tujuan penelitian ini adalah untuk mengetahui dan memperoleh bukti empiris bahwa:

1) Kemandirian Keuangan Daerah berpengaruh terhadap Alokasi Belanja Modal

2) Ketergantungan Keuangan Daerah berpengaruh terhadap Alokasi Belanja Modal

3) Efektivitas PAD berpengaruh terhadap Alokasi Belanja Modal

4) Efektivitas Belanja Modal berpengaruh terhadap Alokasi Belanja Modal

5) Efisiensi Keuangan Daerah berpengaruh terhadap Alokasi Belanja Modal

6) Keserasian Belanja berpengaruh terhadap Alokasi Belanja Modal

7) Kemandirian Keuangan Daerah, Ketergantungan Keuangan Daerah, Efektivitas PAD, Efektivitas Belanja Modal, Efisiensi Keuangan Daerah, Keserasian Belanja berpengaruh terhadap Alokasi Belanja Modal.

\subsection{Manfaat Penelitian}

Adapun manfaat yang diharapkan dari hasil penelitian ini adalah sebagai berikut:

1) Bisa menjadi bahan pertimbangan bagi para pengambil kebijakan di jajaran pemerintah daerah Provinsi Sulawesi Utara dalam pengelolaan keuangan daerah, khususnya dalam hal peningkatan kinerja keuangan daerah dan dalam hal pengalokasian belanja modal.

2) Dapat menambah literatur bagi pihak-pihak yang akan melakukan studi terkait atau penelitian selanjutnya.

\subsection{Tinjauan Pustaka}

Ardhini dan Handayani (2011) melakukan penelitian tentang pengaruh rasio keuangan daerah terhadap belanja modal untuk pelayanan publik dalam perspektif teori keagenan. Variabel independen yang digunakan dalam penelitian ini yaitu: kemandirian daerah, efektivitas keuangan daerah, efisiensi keuangan daerah, dan Silpa. Sedangkan Variabel dependennya adalah belanja modal dan pertumbuhan ekonomi. Dari pengujian yang dilakukan dengan analisis regresi berganda diperoleh hasil yang menyatakan bahwa rasio kemandirian berpengaruh positif tidak signifikan terhadap rasio belanja modal untuk pelayanan publik. Sedangkan rasio efektivitas dan SiLPA berpengaruh positif signifikan terhadap alokasi belanja modal untuk pelayanan public. Rasio Efisiensi berpengaruh negatif namun signifikan terhadap alokasi belanja modal untuk pelayanan public.

Penelitian yang dilakukan Sularso dan Restianto (2011) pada kabupaten/kota di Jawa Tengah bertujuan untuk menganalisis pengaruh kinerja keuangan terhadap alokasi belanja modal dan pertumbuhan ekonomi. Penelitian ini menggunakan metode Structural Equation Modeling (SEM), dengan sampel seluruh kabupaten/kota di Jawa Tengah yang berjumlah 35 kabupaten/kota. Hasil penelitian menunjukan bahwa pengalokasian belanja modal yang dilakukan oleh pemerintah kabupaten/kota di Jawa Tengah dipengaruhi oleh kinerja keuangan khususnya rasio ketergantungan keuangan, rasio kemandirian keuangan, rasio efektivitas PAD dan derajat kontribusi BUMD. Sebaliknya rasio derajat desentralisasi tidak memiliki pengaruh terhadap alokasi belanja modal. Lebih lanjut alokasi belanja modal memberikan pengaruh yang positif terhadap pertumbuhan ekonomi. Hal ini berarti bahwa salah satu fungsi anggaran pemerintah daerah yakni sebagai stimulus perekonomian telah berjalan. Hasil analisis mengindikasikan bahwa salah satu faktor yang mempengaruhi pertumbuhan ekonomi secara tidak langsung adalah kinerja keuangan daerah. Pengaruh tidak langsung terbesar adalah efektivitas PAD. Dengan demikian dapat dinyatakan bahwa dengan otonomi daerah, muncul indikator lain yang mendukung pertumbuhan ekonomi yaitu kinerja keuangan daerah. 


\subsection{Kerangka Konseptual}

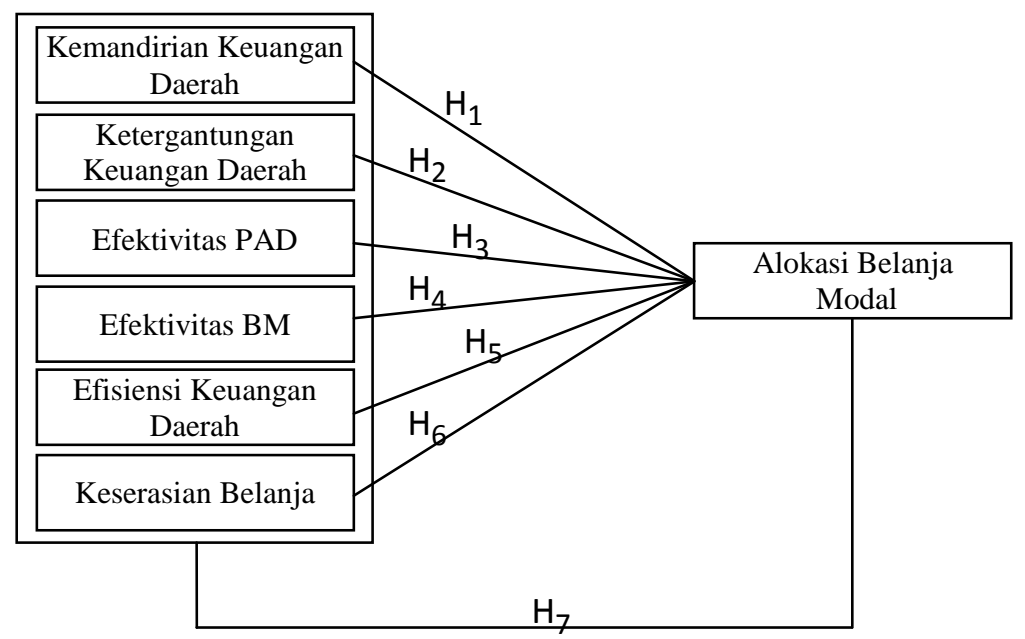

\subsection{Hipotesis}

H1 : Kemandirian Keuangan Daerah berpengaruh secara signifikan terhadap Alokasi Belanja

Modal

$\mathrm{H} 2$

: Ketergantungan Keuangan Daerah berpengaruh secara signifikan terhadap Alokasi Belanja Modal

H3 : Efektivitas PAD berpengaruh secara signifikan terhadap Alokasi Belanja Modal

$\mathrm{H} 4$

H5

H6 : Keserasian Belanja berpengaruh secara signifikan terhadap Alokasi Belanja Modal

H7 : Kemandirian Keuangan Daerah, Ketergantungan Keuangan Daerah, Efektivitas PAD, Efektivitas Belanja Modal, Efisiensi Keuangan Daerah dan Keserasian Belanja berpengaruh secara signifikan terhadap Alokasi Belanja Modal

\section{LANDASAN TEORI}

\subsection{Kinerja Keuangan Pemerintah Daerah}

Menurut Peraturan Pemerintah Republik Indonesia nomor 58 tahun 2005 tentang Pengelolaan Keuangan Daerah dalam ketentuan umumnya, menyatakan bahwa keuangan daerah adalah semua hak dan kewajiban daerah dalam rangka penyelengaraan pemerintah daerah yang dapat dinilai dengan uang termasuk di dalamnya segala bentuk kekayaan daerah tersebut. Kemampuan pemda dalam mengelola keuangan dituangkan dalam Anggaran Pendapatan dan Belanja Daerah (APBD) yang langsung maupun tidak langsung mencerminkan kemampuan pemda dalam membiayai pelaksanaan tugas-tugas pemerintah, pembangunan, dan pelayanan sosial masyarakat. Pemda sebagai pihak yang diserahi tugas menjalankan roda pemerintahan, pembangunan, dan pelayanan masyarakat wajib menyampaikan laporan pertanggungjawaban keuangan daerahnya untuk dinilai apakah pemda berhasil menjalankan tugasnya dengan baik atau tidak. Salah satu alat untuk menganalisis kinerja pemda dalam mengelola keuangan daerahnya adalah dengan melakukan analisis rasio keuangan terhadap APBD yang telah ditetapkan dan dilaksanakannya (Halim, 2007:230).

Hasil analisis rasio keuangan ini selanjutnya digunakan sebagai tolok ukur dalam:

1. Menilai kemandirian keuangan daerah dalam membiayai penyelenggaraan otonomi daerah.

2. Mengukur efektivitas dan efisiensi dalam merealisasikan pendapatan daerah.

3. Mengukur sejauh mana aktivitas pemerintah daerah dalam membelanjakan pendapatan daerahnya.

4. Mengukur kontribusi masing-masing sumber pendapatan dalam pembentukan pendapatan daerah.

5. Melihat pertumbuhan/perkembangan perolehan pendapatan dan pengeluaran yang dilakukan selama periode waktu tertentu.

Adapun pihak-pihak yang berkepentingan dengan rasio keuangan pada APBD ini adalah: 
1. DPRD sebagai wakil dari pemilik daerah (masyarakat).

2. Pihak eksekutif sebagai landasan dalam menyusun APBD berikutnya.

3. Pemerintah pusat/provinsi sebagai bahan masukan dalam membina pelaksanaan pengelolaan keuangan daerah.

4. Masyarakat dan kreditur, sebagai pihak yang akan turut memiliki saham pemda, bersedia memberikan pinjaman ataupun membeli obligasi.

Menurut Mahmudi (2011:169) beberapa rasio keuangan untuk mengukur kinerja keuangan pemerintah, terdiri dari: Derajat Desetnraslisasi, Rasio Ketergantungan Keuangan Daerah, Rasio Kemandirian Keuangan Daerah, Rasio Efektivitas PAD, Rasio Efisiensi PAD, Rasio Efektivitas Pajak, Rasio Efisiensi Pajak, Derajat Kontribusi BUMD. Selain itu terdapat juga rasio aktivitas untuk organisasi pemerintah yang berupa Rasio Keserasian Belanja.

\subsubsection{Kemandirian Keuangan Daerah}

Rasio Kemandirian Keuangan Daerah dihitung dengan cara membandingkan jumlah penerimaan Pendapatan Asli Daerah dibagi dengan jumlah pendapatan transfer dari pemerintah pusat dan propinsi serta pinjaman daerah. Semakin tinggi angka rasio ini menunjukan pemerintah daerah semakin tinggi kemandirian keuangan daerahnya (Mahmudi, 2011:170).

$$
\text { Rasio Kemandirian }=\frac{\text { Pendapatan Asli Daerah }(\text { PAD })}{(\text { Transfer Pusat }+ \text { Propinsi })+\text { Pinjaman }} \times 100 \%
$$

\subsubsection{Ketergantungan Keuangan Daerah}

Rasio ketergantungan keuangan daerah dihitung dengan cara membandingkan jumlah pendapatan transfer yang diterima pemerintah daerah dengan total pendapatan daerah. Semakin tinggi rasio ini maka semakin besar tingkat ketergantungan pemerintah daerah terhadap pemerintah pusat dan/atau pemerintah provinsi. Rasio ini dirumuskan sebagai berikut:

\subsubsection{Efektivitas}

$$
\underset{\text { Ketergantungan }}{\text { Rasio }}=\frac{\text { Pendapatan Transfer }}{\text { Total Pendapatan }} \times 100 \%
$$

Rasio efektivitas pendapatan dihitung dengan cara membandingkan realisasi pendapatan dengan target penerimaan pendapatan yang dianggarkan. Rasio ini dirumuskan sebagai berikut:

$$
\begin{aligned}
& \text { Rasio Efektivitas } \\
& \text { Pendapatan }
\end{aligned} \quad=\frac{\text { Realisasi Penerimaan Pendapatan }}{\text { Target Penerimaan Pendapatan }} \times 100 \%
$$

Rasio efektivitas pendapatan menunjukan kemampuan pemerintah dalam memobilisasi penerimaan pendapatan sesuai dengan yang ditargetkan. Secara umum, nilai efektivitas pendapatan dapat dikategorikan sebagai berikut:

\begin{tabular}{|c|c|}
\hline Sangat efektif & $>100 \%$ \\
\hline Efektif & $100 \%$ \\
\hline Cukup efektif & $90 \%-99 \%$ \\
\hline Kurang efektif & $75 \%-89 \%$ \\
\hline Tidak efektif & $<75 \%$ \\
\hline
\end{tabular}

Rasio ini juga dapat digunakan untuk melihat efektivitas belanja, yaitu dengan membandingkan realisasi belanja dan target belanja.

\subsubsection{Efisiensi}

Rasio efisiensi pendapatan dihitung dengan cara membandingkan biaya yang dikeluarkan untuk memperoleh pendapatan dengan realisasi penerimaan pendapatan. Rasio efisiensi pendapatan dirumsukan sebagai berikut:

$$
\text { Rasio Efisiensi } \quad=\frac{\text { Realisasi Belanja }}{\text { Realisasi Pendapatan }} \times 100 \%
$$


Semakin kecil nilai rasio efisiensi ini maka semakin baik kinerja pemerintah dalam melakukan pemungutan pendapatan. Secara umum, nilai rasio efisiensi pendapatan dapat dikategorikan sebagai berikut:

\begin{tabular}{|c|c|}
\hline Sangat efisien & $<60 \%$ \\
\hline Efisien & $60 \%-80 \%$ \\
\hline Cukup efisien & $80 \%-90 \%$ \\
\hline Kurang efisien & $90 \%-100 \%$ \\
\hline Tidak efisien & $<100 \%$ \\
\hline
\end{tabular}

\subsubsection{Keserasian Belanja}

Rasio Keserasian Belanja menggambarkan bagaimana pemda memprioritaskan alokasi dananya pada belanja rutin dan belanja pembangunan secara optimal. Semakin tinggi persentase dana yang dialokasikan untuk belanja rutin berarti persentase belanja investasi (pembangunan) yang digunakan untuk menyediakan sarana dan prasarana ekonomi masyarakat cenderung semakin kecil.

$$
\begin{array}{ccc}
\text { Rasio Belanja Rutin terhadap APBD } & =\frac{\text { Total Belanja Rutin }}{\text { Total APBD }} \\
\begin{array}{cc}
\text { Rasio Belanja Pembangunan terhadap } \\
\text { APBD }
\end{array} & =\frac{\text { Total Belanja }}{\text { Pembangunan }} \\
\hline
\end{array}
$$

Belum ada tolok ukur yang pasti berapa besarnya rasio belanja rutin maupun pembangunan terhadap APBD yang ideal, karena sangat dipengaruhi oleh dinamisasi kegiatan pembangunan dan besarnya kebutuhan investasi yang diperlukan untuk mencapai pertumbuhan yang ditargetkan (Halim, 2007:235).

\subsubsection{Pertumbuhan}

Rasio Pertumbuhan mengukur seberapa besar kemampuan pemerintah daerah dalam mempertahankan dan meningkatkan keberhasilan yang telah dicapai dari periode ke periode berikutnya. Dengan diketahuinya pertumbuhan untuk masing-masing komponen sumber pendapatan dan pengeluaran, dapat digunakan mengevaluasi potensi-potensi mana yang perlu mendapat perhatian.

$$
\mathrm{r}=\frac{\mathrm{P}_{\mathrm{n}-\mathrm{P}_{\mathrm{o}}}}{\mathrm{P}_{\mathrm{o}}} \times 100 \%
$$

Keterangan:

$\mathrm{P}_{\mathrm{n}}$

: Data yang dihitung pada tahun ke-n

$\mathrm{P}_{\mathrm{O}} \quad$ : Data yang dihitung pada tahun ke-o

r : Pertumbuhan

\subsection{Belanja Modal}

Menurut Warren (2008:450), Belanja Modal adalah biaya akuisisi atas aset tetap, biaya atas penambahan atau perbaikan pada aset tetap sendiri yang meningkatkan nilai total aset, atau memperpanjang umur manfaatnya. Menurut PP nomor 71 tahun 2010 tentang Standar Akuntansi Pemerintahan, Belanja Modal adalah pengeluaran anggaran untuk perolehan aset tetap dan aset lainnya yang memberi manfaat lebih dari satu periode akuntansi. Belanja modal meliputi antara lain belanja untuk perolehan tanah, gedung dan bangunan, peralatan, aset tak berwujud. Menurut Peraturan Menteri Dalam Negeri nomor 13 tahun 2006 tentang Pedoman Pengelolaan Keuangan Daerah, Belanja Modal adalah pengeluaran yang dilakukan dalam rangka pembelian/pengadaan atau pembangunan aset tetap berwujud yang mempunyai nilai manfaat lebih dari 12 (duabelas) bulan untuk digunakan dalam kegiatan pemerintahan, seperti dalam bentuk tanah, peralatan dan mesin, gedung dan bangunan, jalan, irigasi dan jaringan, dan aset tetap lainnya.

Standar Akuntansi Pemerintahan mendefinisikan aset tetap sebagai aset berwujud yang mempunyai masa mafaat lebih dari 12 (dua belas) bulan untuk digunakan, atau dimaksudkan untuk 
digunakan, dalam kegiatan pemerintah atau dimanfaatkan oleh masyarakat umum. Aset tetap diklasifikasikan berdasarkan kesamaan dalam sifat atau fungsinya dalam aktivitas operasi entitas.

Klasifikasi aset tetap adalah sebagai berikut:

1. Tanah

2. Peralatan dan Mesin

3. Gedung dan Bangunan

4. Jalan, Irigasi dan Jaringan

5. Aset Tetap Lainnya

6. Konstruksi dalam Pengerjaan.

Aset tetap diakui pada saat manfaat ekonomi masa depan dapat diperoleh dan nilainya dapat diukur dengan handal. Untuk dapat diakui sebagai aset tetap harus dipenuhi kriteria berikut:

1. Berwujud

2. Mempunyai manfaat lebih dari 12 (dua belas) bulan

3. Biaya perolehan aset dapat diukur secara andal

4. Tidak dimaksudkan untuk dijual dalam operasi normal entitas

5. Diperoleh atau dibangun dengan maksud untuk digunakan

Aset tetap dinilai dengan biaya perolehan. Apabila penilaian aset tetap dengan menggunakan biaya perolehan tidak memungkinkan maka nilai aset tetap didasarkan pada nilai wajar pada saat perolehan.

\section{METODE PENELITIAN}

\subsection{Jenis dan Sumber Data}

Jenis data yang digunakan dalam penelitian ini adalah data kuantitatif yaitu data-data pada laporan realisasi anggaran dan APBD. Berdasarkan sumbernya data yang digunakan dalam penelitian ini adalah data sekunder karena data diperoleh dari Badan Pengelolaan Keuangan dan Barang Milik Daerah (BPKBMD) Provinsi Sulawesi Utara, dan dari situs resmi Direktorat Jendral Perimbangan Keuangan.

\subsection{Teknik Pengumpulan Data}

Laporan keuangan pemerintah kabupaten dan kota Provinsi Sulawesi Utara diperoleh dari Badan Pengelolaan Keuangan dan Barang Milik Daerah (BPKBMD) Provinsi Sulawesi Utara, dan dari situs resmi Direktorat Jendral Perimbangan Keuangan.

\subsection{Populasi dan Sampel}

Populasi dalam penelitian ini adalah laporan keuangan pemerintah daerah (LKPD) kabupaten dan kota di Provinsi Sulawesi Utara yang berjumlah 15. Sampel dari penelitian ini adalah data time series LKPD yang berupa APBD dan Laporan Realisasi Anggaran (LRA) kabupaten dan kota di Provinsi Sulawesi Utara mulai dari tahun 2007 sampai dengan tahun 2011.

Sampel Penelitian

\begin{tabular}{|c|l|c|c|c|}
\hline No. & \multicolumn{1}{|c|}{ Nama Kabupaten/Kota } & $\begin{array}{c}\text { Jumlah } \\
\text { Sampel }\end{array}$ & $\begin{array}{c}\text { Sampel } \\
\text { data } \\
\text { ekstrim }\end{array}$ & $\begin{array}{c}\text { Sampel } \\
\text { yang } \\
\text { digunakan }\end{array}$ \\
\hline 1 & Kab. Bolaang Mongondow & 5 & 1 & 4 \\
\hline 2 & $\begin{array}{l}\text { Kab. Bolaang Mongondow } \\
\text { Selatan }\end{array}$ & 3 & - & 3 \\
\hline 3 & $\begin{array}{l}\text { Kab. Bolaang Mongondow } \\
\text { Timur }\end{array}$ & 3 & - & 3 \\
\hline 4 & $\begin{array}{l}\text { Kab. Bolaang Mongondow } \\
\text { Utara }\end{array}$ & 4 & - & 4 \\
\hline 5 & $\begin{array}{l}\text { Kab. Kep. Siau Tagulandang } \\
\text { Biaro }\end{array}$ & 4 & - & 4 \\
\hline 6 & Kab. Kep. Talaud & 5 & - & 5 \\
\hline 7 & Kab. Minahasa & 5 & - & 5 \\
\hline
\end{tabular}




\begin{tabular}{|c|l|c|c|c|}
\hline 8 & Kab. Minahasa Selatan & 5 & - & 5 \\
\hline 9 & Kab. Minahasa Tenggara & 4 & - & 4 \\
\hline 10 & Kab. Minahasa Utara & 5 & - & 5 \\
\hline 11 & Kab. Sangihe & 5 & 1 & 4 \\
\hline 12 & Kota Bitung & 5 & - & 5 \\
\hline 13 & Kota Kotamobagu & 4 & - & 4 \\
\hline 14 & Kota Manado & 5 & - & 5 \\
\hline 15 & Kota Tomohon & 5 & - & 5 \\
\hline \multicolumn{2}{|c|}{ Total Sampel } & $\mathbf{6 7}$ & $\mathbf{2}$ & $\mathbf{6 5}$ \\
\hline
\end{tabular}

Dalam pengujian asumsi klasik khususnya uji normalitas, ditemukan 2 sampel yang memiliki data ekstrim, yaitu data yang memiliki nilai terlampau besar dibandingkan dengan data yang lain dalam kelompok variabel yang sama. Kedua sampel ini dieliminasi karena dapat menyebabkan data tidak terdistribusi normal. Jumlah sampel yang digunakan dalam penelitian ini semula berjumlah 67 sampel, setelah dilakukan eliminasi 2 sampel yang memiliki data ekstrim, jumlah sampel yang digunakan menjadi 65 sampel.

\subsection{Definisi dan Pengukuran Variabel}

Variabel-variabel dalam penelitian ini adalah sebagai berikut:

1. Kemandirian Keuangan Daerah $\left(\mathrm{X}_{1}\right)$, variabel ini adalah variabel independen yang merupakan perbandingan antara PAD dengan Transfer Pusat/Provinsi dan Pinjaman, dinyatakan dalam skala rasio.

2. Ketergantungan Keuangan Daerah $\left(\mathrm{X}_{2}\right)$, variabel ini adalah variabel independen yang merupakan perbandingan antara Pendapatan Transfer dengan Total Pendapatan Daerah, dinyatakan dalam skala rasio.

3. Efektivitas $\mathrm{PAD}\left(\mathrm{X}_{3}\right)$, variabel ini adalah variable independen yang merupakan perbandingan antara Realisasi Penerimaan PAD dengan Anggaran PAD, dinyatakan dalam skala rasio.

4. Efektivitas Belanja Modal $\left(\mathrm{X}_{4}\right)$, variabel ini adalah variable independen yang merupakan perbandingan antara Realisasi Belanja Modal dengan Anggaran Belanja Modal, dinyatakan dalam skala rasio.

5. Efisiensi Keuangan Daerah $\left(\mathrm{X}_{5}\right)$, variabel ini adalah variabel independen yang merupakan perbandingan antara Realisasi Total Belanja dengan Realisasi Total Pendapatan, dinyatakan dalam skala rasio.

6. Keserasian Belanja $\left(\mathrm{X}_{6}\right)$, variabel ini adalah variabel independen yang merupakan perbandingan antara Realisasi Belanja Modal dengan Realisasi Total Belanja, dinyatakan dalam skala rasio.

7. Alokasi Belanja Modal (Y), variabel ini adalah variabel dependen yang merupakan perbandingan antara Anggaran Belanja Modal dengan Anggaran Total Belanja, dinyatakan dalam skala rasio. Alokasi Belanja Modal yang digunakan dalam penelitian ini adalah data belanja modal pada APBD di tahun berikutnya.

\subsection{Metode Analisis}

Metode analisis yang digunakan dalam penelitian ini adalah regresi sederhana dan regresi linier berganda. Analisis regresi sederhana digunakan untuk mengukur pengaruh antara satu variabel independen terhadap variabel dependen. Analisis regresi linier berganda digunakan untuk mengukur pengaruh antara lebih dari satu variabel independen terhadap variable dependen. Rumus analisis regresi berganda yaitu:

$Y=a+b_{1} X_{1}+b_{2} X_{2}+b_{3} X_{3}+b_{4} X_{4}+b_{5} X_{5}+b_{6} X_{6}$

$\mathrm{Y} \quad$ : Alokasi Belanja Modal

$\mathrm{X}_{1} \quad$ : Kemandirian Keuangan Daerah

$\mathrm{X}_{2} \quad$ : Ketergantungan Keuangan Daerah

$\mathrm{X}_{3}$ : Efektivitas PAD

$\mathrm{X}_{4}$ : Efektivitas BM 
$\mathrm{X}_{5} \quad$ : Efisiensi Keuangan Daerah

$\mathrm{X}_{6} \quad$ : Keserasian Belanja

a : Konstanta

b : Koefisien regresi

Sebelum melakukan analisis regresi, terlebih dahulu perlu dilakukan pengujian asumsi klasik yang meliputi pengujian normalitas, linearitas, homoskedastisitas, multikolinearitas, dan autokorelasi (Santoso, 2010:203).

a. Uji Normalitas

Alat uji ini digunakan untuk mengetahui apakah dalam sebuah model regresi nilai residu dari regresi mempunyai distribusi yang normal. Jika distribusi dari nilai-nilai residual tersebut tidak dapat dianggap berdistribusi normal maka dikatakan ada masalah terhadap asumsi normalitas. Pengujian ini secara praktis dilakukan lewat pembuatan grafik normal probability plot.

b. Uji Homoskedastisitas

Alat uji ini digunakan untuk mengetahui apakah dalam sebuah model regresi terjadi ketidaksamaan varians residual dari satu pengamatan ke pengamatan yang lain. Jika varian residual dari satu pengamatan ke pengamatan yang lain tetap, maka hal tersebut disebut homoskedastisitas. Dan jika varians berbeda, disebut sebagai heteroskedastisitas. Model regresi yang baik adalah tidak terjadi heteroskedastisitas.

c. Uji Multikolinearitas

Alat uji ini digunakan untuk mengetahui apakah pada model regresi ditemukan adanya korelasi antar-variabel independen. Jika terjadi korelasi maka dinamakan terdapat probelm Multikolinearitas (Multiko). Model regresi yang baik seharunya tidak terjadi korelasi di antara variabel independen.

d. Uji Autokorelasi

Uji Autokorelasi bertujuan menguji apakah dalam suatu model regresi liner ada korelasi antara kesalahan pengganggu pada periode $\mathrm{t}$ dengan kesalahan pada periode t-1 atau sebelumnya. Jika terjadi korelasi, maka dinamakan ada problem autokorelasi. Model regresi yang baik adalah regresi yang bebas dari autokorelasi.

\section{HASIL PENELITIAN DAN PEMBAHASAN}

\subsection{Pengujian Asumsi Klasik}

\subsubsection{Multikolinieritas}

Uji Multikolinieritas bertujuan untuk menguji apakah dalam model regresi ditemukan adanya korelasi yang tinggi atau sempurna antarvariabel independen. Uji Multikolinieritas dilakukan dengan melihat nilai Tolerance dan Variance Inflastion Factor (VIF). Sebuah model regresi yang tidak terjadi multikoliniertias antarvariabel independennya ditandai dengan nilai Tolerance $>0,10$ dan VIF $<10$. Tabel 4.1. menunjukan nilai Tolerance semua variabel independen berada di atas 0,10 dan nilai VIF di bawah 10. Maka dapat disimpulkan tidak terdapat multikolinieritas pada kelima variabel independen dalam penelitian ini. Pada Tabel 4.2. menunjukan Pari-wise correlation antarvariabel independen semuanya di bawah 0,80 sehingga dapat disimpulkan bahwa tidak terdapat multikolinieritas antarvariabel independen.

Tabel 4.1. Uji Multikolinieritas 1

\begin{tabular}{|c|c|c|c|c|c|c|c|c|}
\hline \multicolumn{9}{|c|}{ Coefficients $^{\Xi}$} \\
\hline & & \multicolumn{2}{|c|}{ Unstandardized Coefficients } & $\begin{array}{c}\text { Standardized } \\
\text { Coefficients }\end{array}$ & \multirow[b]{2}{*}{$t$} & \multirow[b]{2}{*}{ Sig. } & \multicolumn{2}{|c|}{ Collinearity Statistics } \\
\hline \multicolumn{2}{|c|}{ Madel } & $\mathrm{B}$ & Std. Error & Beta & & & Tolerance & VIF \\
\hline \multirow[t]{7}{*}{1} & (Constant) & 35.194 & 22.349 & & 1.575 & .121 & & \\
\hline & $\mathrm{KmD}$ & -.657 & .317 & -.236 & -2.070 & .043 & .694 & 1.441 \\
\hline & $\mathrm{Ktg} \mathrm{D}$ & -.222 & .162 & -.143 & -1.369 & .176 & .828 & 1.208 \\
\hline & Efektivitas & .026 & .023 & .132 & 1.159 & .251 & .700 & 1.429 \\
\hline & EfkBM & .075 & .031 & .261 & 2.420 & .019 & .775 & 1.290 \\
\hline & Efisiensi & -.087 & .172 & -.056 & -.507 & .614 & .749 & 1.335 \\
\hline & $\mathrm{KsB}$ & .432 & .110 & .464 & 3.940 & .000 & .650 & 1.539 \\
\hline
\end{tabular}

a. Dependent Variable: ABM 
Tabel 4.2. Uji Multikolinieritas 2

Coefficient Correlations ${ }^{a}$

\begin{tabular}{|c|c|c|c|c|c|c|c|c|}
\hline \multicolumn{3}{|c|}{ Madel } & $\mathrm{KsB}$ & Efisiensi & $\mathrm{Ktg} \mathrm{D}$ & EfkBM & Efektivitas & $\mathrm{KmD}$ \\
\hline \multirow[t]{12}{*}{1} & Correlations & $\mathrm{KsB}$ & 1.000 & -.098 & .221 & .050 & -.476 & .396 \\
\hline & & Efisiensi & -.098 & 1.000 & -.149 & .398 & .247 & -.272 \\
\hline & & $\mathrm{Ktg} D$ & .221 & -.149 & 1.000 & -.125 & -.140 & .385 \\
\hline & & EfkBM & .050 & .398 & -.125 & 1.000 & .219 & .017 \\
\hline & & Efektivitas & -.476 & .247 & -.140 & .219 & 1.000 & -.187 \\
\hline & & $\mathrm{KmD}$ & .396 & -.272 & .385 & .017 & -.187 & 1.000 \\
\hline & Covariances & $\mathrm{KsB}$ & .012 & -.002 & .004 & .000 & -.001 & .014 \\
\hline & & Efisiensi & -.002 & .029 & -.004 & .002 & .001 & -.015 \\
\hline & & KtgD & .004 & -.004 & .026 & .000 & .000 & .020 \\
\hline & & EfkBM & .000 & .002 & .000 & .001 & .000 & .000 \\
\hline & & Efektivitas & -.001 & .001 & .000 & .000 & 001 & -.001 \\
\hline & & $\mathrm{KmD}$ & .014 & -.015 & .020 & .000 & -.001 & .101 \\
\hline
\end{tabular}

a. Dependent Variable: ABM

\subsubsection{Sumber: Data Olahan}

Untuk mendeteksi ada tidaknya heteroskedastisitas pada model regresi, metode yang digunakan dalam penelitian ini adalah Scatterplot dan uji Glejser. Grafik Scatterplot menunjukan titik-titik tidak menyebar secara acak, sehingga dapat disimpulkan terjadi heteroskedastisitas pada model regresi. Namun, metode grafik memiliki kelemahan yang cukup signifikan oleh karena jumlah observasi mempengaruhi hasil plotting. Untuk itu pengujian dilanjutkan dengan menggunakan metode statistik yaitu uji Glesjer.

\section{Gambar 4.1. Grafik Scatterplot}

Dependent Variable: ABM

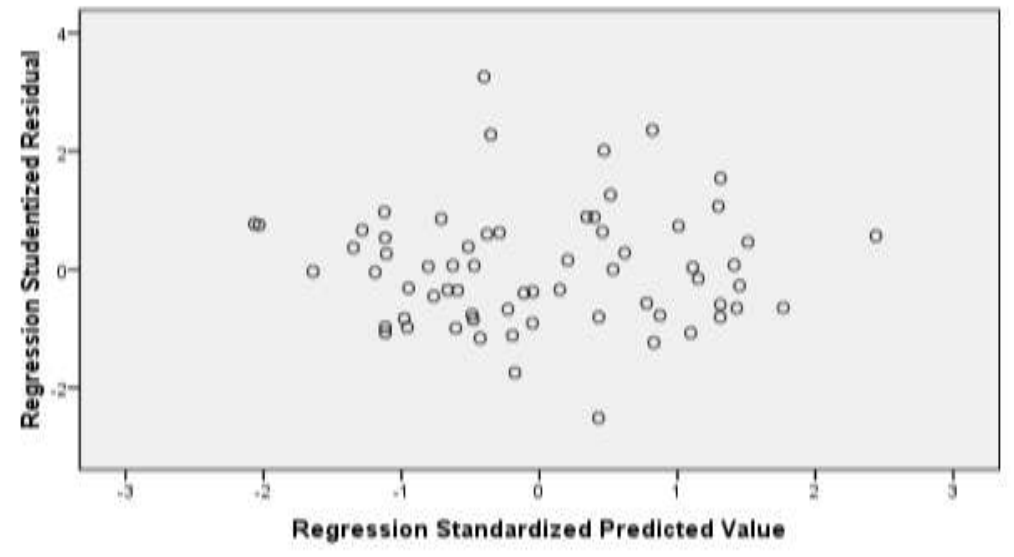

Sumber: Data Olahan

Uji Glesjer dilakukan dengan meregresikan nilai absolute residual (AbsUi) terhadap variabel independen. Jika hasilnya signifikan, maka mengindikasikan terdapat heteroskedastisitas dalam model regresi (Jenie, 2012:26). 
Tabel 4.3. Uji Glesjer

Coefficients $^{\beth}$

\begin{tabular}{|c|c|c|c|c|c|c|}
\hline \multirow[b]{2}{*}{ Mad } & & \multicolumn{2}{|c|}{ Unstandardized Coefficients } & \multirow{2}{*}{ 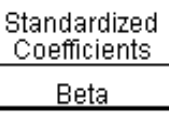 } & \multirow[b]{2}{*}{$t$} & \multirow[b]{2}{*}{ Siq. } \\
\hline & & B & Std. Error & & & \\
\hline \multirow[t]{7}{*}{1} & (Constant) & 36.225 & 13.294 & & 2.725 & .008 \\
\hline & $\mathrm{KmD}$ & -.322 & .189 & -.253 & -1.709 & .093 \\
\hline & $\mathrm{Ktg} \mathrm{D}$ & -.144 & .096 & -.203 & -1.495 & .140 \\
\hline & Efektivitas & -.008 & .013 & -.087 & -.587 & .559 \\
\hline & EfkBM & -.018 & .018 & -.139 & -.992 & .325 \\
\hline & Efisiensi & -.128 & .102 & -.179 & -1.255 & .214 \\
\hline & $\mathrm{KsB}$ & -.049 & .065 & -.115 & -.754 & .454 \\
\hline
\end{tabular}

a Denendent Variahle: Ahs! lj

Sumber: Data Olahan

Hasil uji Glesjer menunjukan nilai signifikansi variabel independen berada di atas 0,01 yaitu sebesar 0,$93 ; 0,140 ; 0,559 ; 0,325 ; 0,214$ dan 0,454 . Hal ini berarti tidak terdapat heteroskedastisitas dalam model regresi ini.

\subsubsection{Autokorelasi}

Uji autokorelasi bertujuan menguji apakah dalam suatu model regresi linier terdapat korelasi antar kesalahan pengganggu (residual) pada periode $t$ dengan kesalahan pada periode $\mathrm{t}-1$. Jika terjadi korelasi, maka dinamakan terdapat permasalahan autokorelasi. Salah satu cara yang umum digunakan untuk mendeteksi adanya autokorelasi dalam regresi linier berganda adalah Uji Durbin Watson (Janie, 2012:30). Suatu model regresi dinyatakan tidak terdapat permasalahan autokorelasi apabila:

$$
d_{u}<d<4-d_{u}
$$

Di mana:

$\mathrm{d}=$ nilai Durbin Watson hitung

$\mathrm{d}_{\mathrm{u}}=$ nilai batas atas/ upper Durbin Watson tabel

\section{Tabel 4.4. Uji Durbin Watson}

Model Summary
\begin{tabular}{|c|c|c|c|c|c|}
\hline Model & $\mathrm{R}$ & R Square & $\begin{array}{c}\text { Adjusted R } \\
\text { Square }\end{array}$ & $\begin{array}{c}\text { Std. Error of } \\
\text { the Estimate }\end{array}$ & $\begin{array}{c}\text { Durbin- } \\
\text { Watson }\end{array}$ \\
\hline 1 & $.691^{\mathrm{a}}$ & .477 & .423 & 7.35600 & 1.876 \\
\hline
\end{tabular}
a. Predictors: (Constant), KsB, Efisiensi, KtgD, EfkBM, EfkPAD, KmD
b. Dependent Variable: ABM

Sumber: Data Olahan

Hasil uji Durbin Watson adalah sebesar 1,876. Nilai ini lebih besar bila dibandingkan dengan batas bawah (dl) tabel Durbin Watson yaitu sebesar 1,404 dan batas atas (du) sebesar 1,804. Karena 1,804 $<1,876<4-1,804$ maka dapat disimpulkan tidak terdapat autokorelasi dalam model regresi ini.

\subsubsection{Normalitas}

Grafik Histogram Uji Normalitas memberikan pola distribusi yang tidak normal. Sedangkan grafik normal plot terlihat titik-titik menyebar di sekitar garis diagonal serta penyebarannya mengikuti arah garis diagonal tersebut. Hal ini menunjukan bahwa data telah terdistribusi normal. 
Gambar 4.2. Grafik Histogram

Dependent Variable: ABM

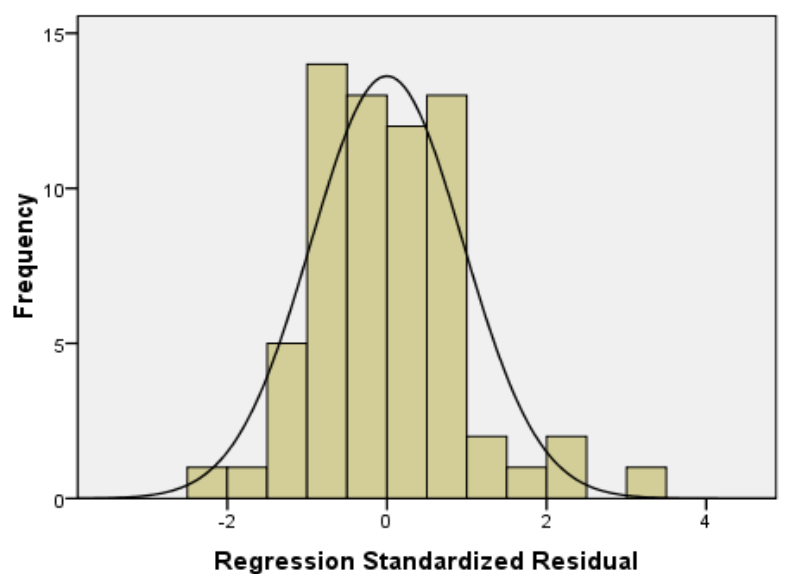

Mean $=-2.39 \mathrm{E}-16$
Std. Dev. $=0.952$

Sumber: Data Olahan

Gambar 4.3. Grafik Normal Plot

Dependent Variable: ABM

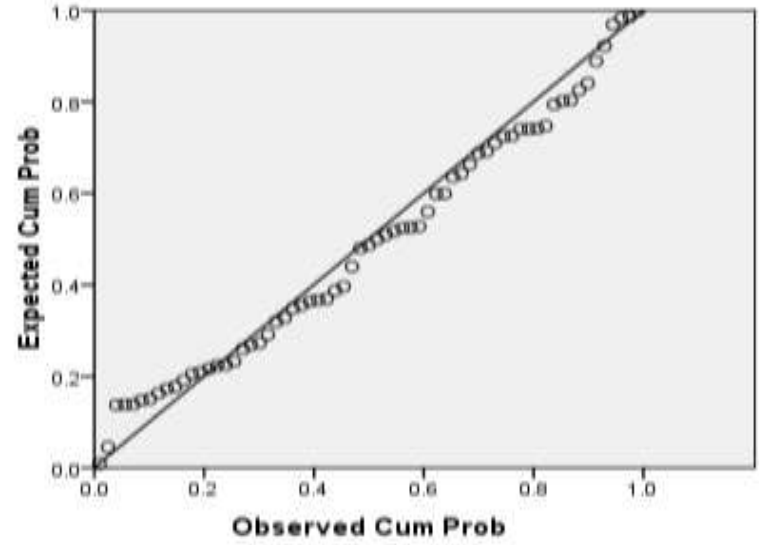

Sumber: Data Olahan

Uji statistik juga perlu dilakukan untuk melengkapi pengujian dengan grafik histogram dan grafik normal plot. Uji statistik yang dilakukan dalam penelitian ini adalah Uji Kolmogorov Smirnov $(\mathrm{KS})$.

Tabel 4.5. Uji Kolmogorov Smirnov

One-Sample Kolmogorov-Smirnow Test

\begin{tabular}{|ll|r|}
\hline & & $\begin{array}{r}\text { Unstandardiz } \\
\text { ed Residual }\end{array}$ \\
\hline Normal Parameters ${ }^{\mathrm{a}, \mathrm{b}}$ & Mean & 65 \\
& Std. Deviation & .0000000 \\
Most Extreme Differences & Absolute & 7.00270149 \\
& Positive & .094 \\
& Negative & .073 \\
Kolmogorov-Smirnov $Z$ & & -.094 \\
Asymp. Sig. (2-tailed) & & .761 \\
\end{tabular}

a. Test distribution is Normal.

b. Calculated from data.

Besarnya nilai Kolmogorov-Smirnov adalah 0,761 dengan tingkat signifikansi jauh di atas 0,05 yaitu 0,609. Dengan kata lain bahwa nilai KS tidak signifikan, berarti residual terdistribusi secara normal. 


\subsection{Pengujian Hipotesis}

\subsubsection{Uji Parsial}

Pengujian secara parsial dilakukan dengan menggunakan analisis regresi linier sederhana. Hasil yang diperoleh adalah sebagai berikut:

Tabel 4.6. Hasil Uji Parsial

\begin{tabular}{|c|c|c|c|c|c|}
\hline $\begin{array}{c}\text { Variabel } \\
\text { Independen }\end{array}$ & Sig. & t-hit & Model Regresi & $\mathrm{R}$ & Kesimpulan \\
\hline $\mathrm{KmD}$ & 0,001 & $\begin{array}{c}- \\
3,357 \\
\end{array}$ & $\mathrm{ABM}=30,897-1,084 \mathrm{KmD}$ & 0,389 & $\begin{array}{c}\mathrm{H} 1 \\
\text { Diterima }\end{array}$ \\
\hline KtgD & 0,609 & $\begin{array}{c}- \\
0,515 \\
\end{array}$ & $\mathrm{ABM}=36,316-0,100 \mathrm{KtgD}$ & 0,065 & H2 Ditolak \\
\hline EfkPAD & 0,011 & 2,631 & $\begin{array}{c}\mathrm{ABM}=19,938+0,062 \\
\text { EfkPAD }\end{array}$ & 0,315 & $\begin{array}{c}\mathrm{H} 3 \\
\text { Diterima } \\
\end{array}$ \\
\hline EfkBM & 0,105 & 2,137 & $\mathrm{ABM}=65,998-0,407 \mathrm{EfkBM}$ & 0,260 & H4 Ditolak \\
\hline Efisiensi & 0,036 & $\begin{array}{c}- \\
2,137\end{array}$ & $\begin{array}{c}\mathrm{ABM}=65,998-0,407 \\
\text { Efisiensi }\end{array}$ & 0,260 & $\begin{array}{c}\text { H5 } \\
\text { Diterima }\end{array}$ \\
\hline $\mathrm{KsB}$ & 0,000 & 5,580 & $\mathrm{ABM}=11,571-0,535 \mathrm{KsB}$ & 0,575 & $\begin{array}{c}\mathrm{H} 6 \\
\text { Diterima }\end{array}$ \\
\hline
\end{tabular}

Sumber: Data Olahan

\subsubsection{Pengaruh Kemandirian Keuangan Daerah terhadap Alokasi Belanja Modal}

Berdasarkan hasil uji statistik Variabel Kemandirian Keuangan Daerah memiliki probabilitas signifikansi sebesar 0,001 lebih kecil dari $\alpha=0,05$ dan t-hitung 3,357 lebih besar dari t-tabel 1,998. Ini berarti Variabel Kemandirian Keuangan Daerah berpengaruh secara signifikan terhadap Alokasi Belanja Modal. Nilai t-hitung negatif menunjukan bahwa Variabel Kemandirian Keuangan Daerah memiliki pengaruh negatif terhadap Alokasi Belanja Modal. Maka dapat disimpulkan variabel Kemandirian Keuangan Daerah berpengaruh signifikan negatif terhadap Alokasi Belanja Modal. Model regersi dari pengaruh Variabel Kemandirian Keuangan Daerah terhadap Alokasi Belanja Modal adalah Y = 30,897 1,084X. Model regresi ini berarti jika Variabel Kemandirian Keuangan Daerah dianggap konstan maka Alokasi Belanja Modal adalah sebesar 30,897\%. Jika variabel Kemandirian Keuangan Daerah mengalami kenaikan sebesar 1\% maka Alokasi Belanja Modal akan mengalami penurunan sebesar 1,084\%. Nilai R sebesar 0,389 memiliki arti bahwa 38,90\% Variabel Alokasi Belanja Modal dapat dijelaskan dengan variabel Kemandirian Keuangan Daerah, sedangkan 61,10\% dijelaskan oleh faktorfaktor lain di luar model.

\subsubsection{Pengaruh Ketergantungan Keuangan Daerah terhadap Alokasi Belanja Modal}

Berdasarkan hasil uji statistik Variabel Ketergantung Keuangan Daerah memiliki probabilitas signifikansi sebesar 0,609 lebih besar dari $\alpha=0,05$ dan nilai t-hitung sebesar 0,515 lebih kecil dari t-tabel 1,998. Ini berarti variabel Ketergantungan Keuangan Daerah tidak memiliki pengaruh signifikan terhadap Alokasi Belanja Modal. Model regersi dari pengaruh Variabel Ketergantungan Keuangan Daerah terhadap Alokasi Belanja Modal adalah $\mathrm{Y}=36,316-0,1 \mathrm{X}$. Model regresi ini berarti jika variabel Ketergantungan Keuangan Daerah dianggap konstan maka Alokasi Belanja Modal adalah sebesar 36,316\%. Jika variabel Ketergantungan Keuangan Daerah mengalami kenaikan sebesar $1 \%$ maka Alokasi Belanja Modal akan mengalami penurunan sebesar 0,1\%. Nilai $\mathrm{R}$ sebesar 0,065 memiliki arti bahwa 6,5\% variabel Alokasi Belanja Modal dapat dijelaskan dengan variabel Ketergantungan Keuangan Daerah, sedangkan 93,5\% dijelaskan oleh faktor-faktor lain di luar model.

\subsubsection{Pengaruh Efektivitas PAD terhadap Alokasi Belanja Modal}

Berdasarkan hasil uji statistik Variabel Efektivitas PAD memiliki probabilitas signifikansi sebesar 0,011 lebih kecil dari $\alpha=0,05$ dan nilai t-hitung sebesar 2,631 lebih besar dari t-tabel 1,998. Ini 
berarti variabel Efektivitas PAD berpengaruh secara signifikan terhadap Alokasi Belanja Modal. Nilai thitung positif menunjukan bahwa variabel Efektivitas PAD memiliki pengaruh positif terhadap Alokasi Belanja Modal. Maka dapat disimpulkan variabel Efektivitas PAD berpengaruh signifikan positif terhadap Alokasi Belanja Modal. Model regersi dari pengaruh variabel Efektivitas PAD terhadap Alokasi Belanja Modal adalah $\mathrm{Y}=19,938+0,062 \mathrm{X}$. Model regresi ini berarti jika variabel Efektivitas PAD dianggap konstan maka Alokasi Belanja Modal adalah sebesar 19,938\%. Jika variabel Efektivitas PAD mengalami kenaikan sebesar 1\% maka Alokasi Belanja Modal akan mengalami kenaikan sebesar 0,062 \%. Nilai R sebesar 0,315 memiliki arti bahwa 31,5\% Variabel Alokasi Belanja Modal dapat dijelaskan dengan variabel Kemandirian Keuangan Daerah, sedangkan 68,5\% dijelaskan oleh faktor-faktor lain di luar model.

\subsubsection{Pengaruh Efektivitas Belanja Modal terhadap Alokasi Belanja Modal}

Berdasarkan hasil uji statistik variabel Efektivitas Belanja Modal memiliki probabilitas signifikansi sebesar 0.105 lebih besar dari $\alpha=0,05$ dan nilai t-hitung sebesar 1,645 lebih kecil dari t-tabel 1,998. Ini berarti variabel Efektivitas Belanja Modal tidak memiliki pengaruh signifikan terhadap Alokasi Belanja Modal. Model regersi dari pengaruh variabel Efektivitas Belanja Modal terhadap Alokasi Belanja Modal adalah $\mathrm{Y}=21,229+0,058 \mathrm{X}$. Model regresi ini berarti jika variabel Efektivitas Belanja Modal dianggap konstan maka Alokasi Belanja Modal adalah sebesar 21,229\%. Jika variabel Efektivitas Belanja Modal mengalami kenaikan sebesar 1\% maka Alokasi Belanja Modal akan mengalami kenaikan sebesar 0,058\%. Nilai R sebesar 0,203 memiliki arti bahwa 20,3\% variabel Alokasi Belanja Modal dapat dijelaskan dengan variabel Efektivitas Belanja Modal, sedangkan 79,7\% dijelaskan oleh faktor-faktor lain di luar model.

\subsubsection{Pengaruh Efisiensi terhadap Alokasi Belanja Modal}

Berdasarkan hasil uji statistik variabel Efisiensi memiliki probabilitas signifikansi sebesar 0,036 lebih kecil dari lebih kecil dari $\alpha=0,05$ dan nilai t-hitung sebesar 2,137 lebih besar dari t-tabel 1,998. Ini berarti variabel Efisiensi berpengaruh secara signifikan terhadap Alokasi Belanja Modal. Nilai t-hitung negatif menunjukan bahwa variabel Efisiensi memiliki pengaruh negatif terhadap Alokasi Belanja Modal. Maka dapat disimpulkan variabel Efisiensi berpengaruh signifikan negatif terhadap Alokasi Belanja Modal. Model regersi dari pengaruh variabel Efisiensi terhadap Alokasi Belanja Modal adalah $\mathrm{Y}=$ 65,998 - 0,407X. Model regresi ini berarti jika variabel Efisiensi dianggap konstan maka Alokasi Belanja Modal adalah sebesar 65,998\%. Jika variabel Efisiensi mengalami kenaikan sebesar 1\% maka Alokasi Belanja Modal akan mengalami penurunan sebesar 0,407\%. Nilai R sebesar 0,260 memiliki arti bahwa 26\% variabel Alokasi Belanja Modal dapat dijelaskan dengan variabel Efisiensi, sedangkan $74 \%$ dijelaskan oleh faktor-faktor lain di luar model.

\subsubsection{Pengaruh Keserasian Belanja terhadap Alokasi Belanja Modal}

Berdasarkan hasil uji statistik variabel Keserasian Belanja memiliki probabilitas signifikansi sebesar 0,000 lebih kecil dari $\alpha=0,05$ dan nilai t-hitung sebesar 5.580 lebih besar dari t-tabel 1,998. Ini berarti variabel Keserasian Belanja berpengaruh secara signifikan terhadap Alokasi Belanja Modal. Nilai t hitung positif berarti variabel Keserasian Belanja memiliki pengaruh positif terhadap Alokasi Belanja Modal. Maka dapat disimpulkan variabel Keserasian Belanja berpengaruh signifikan positif terhadap Alokasi Belanja Modal. Model regersi dari pengaruh variabel Keserasian Belanja terhadap Alokasi Belanja Modal adalah Y $=11.571+0,535 X$. Model regresi ini berarti jika variabel Keserasian Belanja dianggap konstan maka Alokasi Belanja Modal adalah sebesar 11,571\%. Jika terjadi kenaikan variabel Keserasian Belanja mengalami kenaikan sebesar 1\% maka Alokasi Belanja Modal akan mengalami kenaikan sebesar 0,535\%. Nilai R sebesar 0,575 memiliki arti bahwa 57,5\% Variabel Alokasi Belanja Modal dapat dijelaskan dengan variabel Keserasian Belanja, sedangkan 42,5\% dijelaskan oleh faktorfaktor lain di luar model. 
Tabel 4.7. Koefisien Determinasi

Model Summary

\begin{tabular}{|c|c|c|c|c|}
\hline Model & $\mathrm{R}$ & R Square & $\begin{array}{c}\text { Adjusted R } \\
\text { Square }\end{array}$ & $\begin{array}{l}\text { Std. Error of } \\
\text { the Estimate }\end{array}$ \\
\hline 1 & $.691^{a}$ & .477 & .423 & 7.35600 \\
\hline
\end{tabular}

Sumber: Data Olahan

Nilai Adjusted R Square sebesar 0,423 yang artinya 42,30\% variabel Alokasi Belanja Modal dapat dijelaskan oleh variabel independen Kemandirian Keuangan Daerah, Ketergantungan Keuangan Daerah, Efektivitas PAD, Efektivitas Belanja Modal, Efisiensi dan Keserasian Belanja. Sedangkan sisanya sebesar $57,7 \%$ dijelaskan oleh faktor-faktor lain di luar model.

\subsubsection{Uji F}

Berdasarkan Tabel 4.8. nilai $\mathrm{F}$ hitung sebesar 8,814 sedangkan $\mathrm{F}$ tabel sebesar 2,2596. Karena $\mathrm{F}$ hitung > F tabel maka dapat disimpulkan bahwa variabel independen secara simultan berpengaruh terhadap variabel dependen. Probabilitas pada tabel ANOVA menunjukan nilai 0,000 yang jauh lebih kecil dari $\alpha=0,05$ sehingga dapat disimpulkan bahwa secara bersama-sama variabel independen berpengaruh signifikan terhadap variabel dependen.

\section{Tabel 4.8. Uji F}

ANOVA $^{\mathrm{B}}$

\begin{tabular}{|ll|r|r|r|r|c|}
\hline \multicolumn{1}{|c|}{} & \multicolumn{1}{|c|}{$\begin{array}{c}\text { Sum of } \\
\text { Model }\end{array}$} & Squares & df & Mean Square & F & Sig. \\
\hline 1 & Regression & 2861.528 & 6 & 476.921 & 8.814 & $.000^{3}$ \\
& Residual & 3138.421 & 58 & 54.111 & & \\
& Total & 5999.949 & 64 & & & \\
\hline
\end{tabular}

a. Predictors: (Constant), KsB, Efisiensi, KtgD, EfkBM, Efektivitas, KmD

b. Dependent Variable: ABM

Sumber: Data Olahan

\subsubsection{Uji t}

Tabel 4.9. Uji t

\begin{tabular}{|c|c|c|c|c|c|c|}
\hline \multicolumn{7}{|c|}{ Coefficients $^{\Xi}$} \\
\hline \multirow[b]{2}{*}{ Made } & & \multicolumn{2}{|c|}{ Unstandardized Coefficients } & \multirow{2}{*}{$\begin{array}{c}\begin{array}{c}\text { Standardized } \\
\text { Coefficients }\end{array} \\
\text { Beta }\end{array}$} & \multirow[b]{2}{*}{$t$} & \multirow[b]{2}{*}{ Sig. } \\
\hline & & $B$ & Std. Error & & & \\
\hline \multirow[t]{7}{*}{1} & (Constant) & 35.194 & 22.349 & & 1.575 & .121 \\
\hline & $\mathrm{KmD}$ & -.657 & .317 & -.236 & -2.070 & .043 \\
\hline & $\mathrm{Ktg} \mathrm{D}$ & -.222 & .162 & -.143 & -1.369 & .176 \\
\hline & Efektivitas & .026 & .023 & .132 & 1.159 & .251 \\
\hline & EfkBM & .075 & .031 & .261 & 2.420 & .019 \\
\hline & Efisiensi & -.087 & .172 & -.056 & -.507 & .614 \\
\hline & $\mathrm{KsB}$ & .432 & .110 & .464 & 3.940 & .000 \\
\hline
\end{tabular}

a. Dependent Variable: ABM

Sumber: Data Olahan 
Hasil uji t menunjukan terdapat 3 (tiga) variabel independen yang memiliki probabilitas signifikansi dibawah $\alpha=0,05$ yaitu Kemandirian Keuangan Daerah sebesar 0,043; Efektivitas Belanja Modal sebesar 0,019; dan Keserasian Belanja sebesar 0,000. Sedangkan 3 (tiga) variabel independen yang lain probabilitas signifikansinya berada di atas $\alpha=0,05$ yaitu Ketergantungan Keuangan Daerah sebesar 0,176; Efektivitas PAD sebesar 0,251; dan Efisiensi sebesar 0,614. Ini berarti variabel Kemandirian Keuangan Daerah, Efektivitas Belanja Modal dan Keserasian Belanja berpengaruh signifikan terhadap variabel dependen Alokasi Belanja Modal, sedangkan variabel Ketergantungan Keuangan Daerah, Efektivitas PAD dan Efisiensi tidak berpengaruh signifikan terhadap variabel dependen Alokasi Belanja Modal. Model persamaan regresinya adalah sebagai berikut:

\section{$\mathrm{ABM}=35,194-0,657 \mathrm{KmD}-0,222 \mathrm{KtgD}+0,026$ Efektivitas PAD $+0,075$ EfkBM - 0,087 Efesiensi + 0,432 KsB}

Interpretasi dari persamaan di atas adalah:

1. Konstanta (a) sebesar 35,194 menyatakan bahwa jika variabel independen dianggap konstan, maka Alokasi Belanja Modal sebesar 35,194\%

2. Koefisien $\mathrm{KmD}$ sebesar -0,657 menunjukan bahwa apabila terjadi perubahan variabel Kemandirian Keuangan Daerah sebesar 1\%, maka Alokasi Belanja Modal akan turun sebesar $0,657 \%$ dengan asumsi variabel lainnya tetap atau sama dengan nol.

3. Koefisien $\mathrm{KtgD}$ sebesar $-0,222$ menunjukan bahwa apabila terjadi perubahan variabel Ketergantungan Keuangan Daerah sebesar 1\%, maka Alokasi Belanja Modal akan turun sebesar $0,222 \%$ dengan asumsi variabel lainnya tetap atau sama dengan nol.

4. Koefisien Efektivitas PAD sebesar 0,026 menunjukan bahwa apabila terjadi perubahan variabel Efektivitas PAD sebesar 1\%, maka Alokasi Belanja Modal akan naik sebesar 0,026\% dengan asumsi variabel lainnya tetap atau sama dengan nol.

5. Koefisien EfkBM sebesar 0,075 menunjukan bahwa apabila terjadi perubahan variabel Efektivitas Belanja Modal sebesar 1\%, maka Alokasi Belanja Modal akan naik sebesar 0,075\% dengan asumsi variabel lainnya tetap atau sama dengan nol.

6. Koefisien Efisiensi sebesar -0,087 menunjukan bahwa apabila terjadi perubahan variabel Efisiensi sebesar 1\%, maka Alokasi Belanja Modal akan turun sebesar 0,087\% dengan asumsi variabel lainnya tetap atau sama dengan nol.

7. Koefisien KsB sebesar 0,432 menunjukan bahwa apabila terjadi perubahan variabel Keserasian Belanja sebesar 1\%, maka Alokasi Belanja Modal akan naik sebesar 0,432\% dengan asumsi variabel lainnya tetap atau sama dengan nol.

\section{KESIMPULAN DAN SARAN}

\subsection{Kesimpulan}

Berdasarkan analisis yang telah dilakukan maka dapat diambil kesimpulan sebagai berikut:

1. Pengujian Hipotesis $1\left(\mathrm{H}_{1}\right)$ dengan analisis regresi sederhana Kemandirian Keuangan Daerah berpengaruh signifikan terhadap Alokasi Belanja Modal, maka hipotesis diterima.

2. Pengujian Hipotesis $2\left(\mathrm{H}_{2}\right)$ dengan analisis regresi sederhana Ketergantungan Keuangan Daerah tidak berpengaruh signifikan terhadap Alokasi Belanja Modal, maka hipotesis ditolak.

3. Pengujian Hipotesis $3\left(\mathrm{H}_{3}\right)$ dengan analisis regresi sederhana Efektivitas PAD berpengaruh signifikan terhadap Alokasi Belanja Modal, maka hipotesis diterima.

4. Pengujian Hipotesis $4\left(\mathrm{H}_{4}\right)$ dengan analisis regresi sederhana Efektivitas Belanja Modal tidak berpengaruh signifikan terhadap Alokasi Belanja Modal, maka hipotesis ditolak.

5. Pengujian Hipotesis $5\left(\mathrm{H}_{5}\right)$ dengan analisis regresi sederhana Efisiensi Keuangan Daerah berpengaruh signifikan terhadap Alokasi Belanja Modal, maka hipotesis diterima.

6. Pengujian Hipotesis $6\left(\mathrm{H}_{6}\right)$ dengan analisis regresi sederhana Keserasian Belanja berpengaruh signifikan terhadap Alokasi Belanja Modal, maka hipotesis diterima.

7. Pengujian Hipotesis $7\left(\mathrm{H}_{7}\right)$ dengan melakukan uji $\mathrm{F}$ variabel Kemandirian Keuangan Daerah, Ketergantungan Keuangan Daerah, Efektivitas PAD, Efektivitas Belanja Modal, Efisiensi, dan Keserasian Belanja secara simultan berpengaruh signifikan terhadap Alokasi Belanja Modal, maka hipotesis diterima. 


\subsection{Saran}

Setelah melihat hasil penelitian ini, saran yang dapat diberikan adalah sebagai berikut:

1) Untuk Pemerintah Daerah, agar berupaya meningkatkan kinerja keuangan daerah karena dapat memberikan dampak pada peningkatan alokasi belanja modal yang merupakan cerminan pembangunan daerah. Pemerintah juga sebaiknya lebih jeli dalam menggali potensi-potensi daerah yang dapat meningkatkan PAD, sehingga dapat tercipta keuangan daerah yang mandiri sesuai dengan tujuan otonomi daerah. Pendapatan transfer dari pemerintah pusat yang masih cukup besar diharapkan dapat dimanfaatkan dengan sabaik-baiknya, tidak hanya untuk membiayai belanja operasional tetapi juga untuk belanja modal. Pemerintah daerah sebagai pihak eksekutif yang menyusun APBD, sebaiknya lebih memperhatikan pengalokasian belanja modal di tahun-tahun yang akan datang terutama belanja modal yang berhubungan langsung dengan kebutuhan masyarakat, seperti pembangunan infrastruktur serta sarana dan prasaran yang dapat meningkatkan kualitas pelayanan publik.

2) Untuk penelitian selanjutnya, sebaiknya menambah sampel dengan memperluas periode pengamatan dan/atau memperluas objek penelitian. Penelitian selanjutnya juga bisa menambah atau mengganti variabel independen, baik berupa variabel keuangan maupun non keuangan, sehingga hasil penelitian yang diperoleh nantinya akan lebih komprehensif dan akurat.

\section{DAFTAR PUSTAKA}

Adi, Priyo Hari. 2006. Hubungan Antara Pertumbuhan Ekonomi Daerah, Belanja Pembangunan dan Pendapatan Asli Daerah (Studi pada Kabupaten dan Kota Se Jawa-Bali). Simposium Akuntansi 9. Padang.

Ardini dan Sri Handayani. 2011. Pengaruh Rasio Keuangan Daerah Terhadap Belanja Modal Untuk Pelayanan Publik Dalam Perspektif Teori Keagenan (Studi pada Kabupaten dan Kota di Jawa Tengah). Jurnal Akuntansi Universitas Diponegoro. Semarang.

Badan Pusat Statistik Provinsi Sulawesi Utara. 2012. Sulawesi Utara Dalam Angka 2012.

Bank Indonesia. 2011. Analisis Keuangan Publik Provinsi Sulawesi Utara 2011: Pengelolaan Keuangan Daerah dan Pembangunan di Bumi Nyiur Melambai. Jakarta.

Bastian, Indra. 2007. Sistem Akuntansi Sektor Publik. Salemba Empat. Jakarta.

Direktorat Jendral Perimbangan Keuangan. Anggaran Pendapatan dan Belanja Daerah. http//:www.djpk.depkeu.go.id

Direktorat Jendral Perimbangan Keuangan. Laporan Realisasi Anggaran. http//:www.djpk.depkeu.go.id

Darwanto dan Yulia Yustikasari. 2007. Pengaruh Pertumbuhan Ekonomi, Pendapatan Asli Daerah dan Dana Alokasi Umum Terhadap Pengalokasian Anggaran Belanja Modal. Simposium Akuntansi X. Makasar.

Fahmi, Irham. 2011. Analisis Kinerja Keuangan. Alfabeta. Bandung.

Fees, Warren Reeve. 2008. Pengantar Akuntansi Edisi 21. Salemba Empat. Jakarta.

Halim, Abdul. 2007. Akuntansi Keuangan Daerah. Edisi 3. Salemba Empat. Jakarta.

Jenie, Dyah Nirmala Arum. 2012. Statistik Deskriptif dan Regresi Linier Berganda Dengan SPSS. Semarang University Press. Semarang

Mahmudi. 2011. Akuntansi Sektor Publik. UII Press Yogyakarta. Yogyakarta.

Mahsun, Mohamad. 2009. Pengukuran Kinerja Sektor Publik. Edisi Pertama. BPFE-Yogyakarta. Yogyakarta.

Mursyidi. 2009. Akuntansi Pemerintahan di Indonesia. Refika Aditama. Bandung.

Prakosa, Kesit Bambang. 2004. Analisis Pengaruh Dana Alokasi Umum (DAU) dan Pendapatan Asli Daerah (PAD) Terhadap Prediksi Belanja Daerah (Studi Empirik di Wilayah Propinsi Jawa Tengah dan DIY). JAAI Vol. 8, No. 2. 
Republik Indonesia. 2003. Undang-undang Republik Indonesia Nomor 17 Tahun 2003. Tentang Keuangan Negara. . 2004. Undang-Undang Republik Indonesia Nomor 1 Tahun 2004 Tentang Perbendaharaan Negara. . 2004. Undang-Undang Republik Indonesia Nomor 32 Tahun 2004 Tentang Pemerintahan Daerah. 2004. Undang-Undang Republik Indonesia Nomor 33 Tahun 2004 Tentang Perimbangan Keuangan Antara Pemerintah Pusat dan Pemerintah Daerah. 2005. Peraturan Pemerintah Republik Indonesia Nomor 58 Tahun 2005 Tentang Pengelolaan Keuangan Daerah. 2000. Peraturan Pemerintah Republik Indonesia Nomor 105 Tahun 2000 Tentang Pengelolaan dan Pertanggungjawaban Keuangan Daerah. . 2010. Peraturan Pemerintah Republik Indonesia Nomor 71 Tahun 2010 Tentang Standar Akuntansi Pemerintahan. 2007. Peraturan Menteri Dalam Negeri Nomor 59 Tahun 2007 Tentang Perubahan

Atas Peraturan Menteri Dalam Negeri No. 13/2006 Tetang Pedoman Pengelolaan Keuangan Daerah.

Santoso, Singgih. 2010. Statistisk Parametrik. PT Elex Media Komputindo. Jakarta.

Setiaji, Wirawan dan Priyo Hari Adi. 2007. Peta Kemampuan Keuangan Daerah Sesudah Otonomi Daerah: Apakah Mengalami Pergeseran? (Studi pada Kabupaten/Kota se-Jawa-Bali). Simposium Nasional Akuntansi X. Makasar.

Simanjuntak, Gunawan. 2009. Pengaruh Transfer Pemerintah Pusat Terhadap Belanja Modal Pemerintah Kabupaten/Kota di Sumatera Utara. Skripsi. Universitas Sumatara Utara. Medan

Sugiyono. 2010. Metode Penelitian Bisnis. Alfabeta. Bandung.

Sularso, Havid dan Yanuar E. Restianto. 2011. Pengaruh Kinerja Keuangan Terhadap Alokasi Belanja Modal dan Pertumbuhan Ekonomi Kabupaten/Kota di Jawa Tengah. Media Riset Akuntansi FEIS Universitas Bakrie. Vol. 1, No. 2. Jakarta.

Sulistyowati, Diah. 2011. Pengaruh Pajak Daerah, Retribusi Daerah, Dana Alokasi Umum, dan Dana Alokasi Khusus Terhadap Alokasi Belanja Modal. Skripsi. Universitas Diponegoro. Semarang. 